
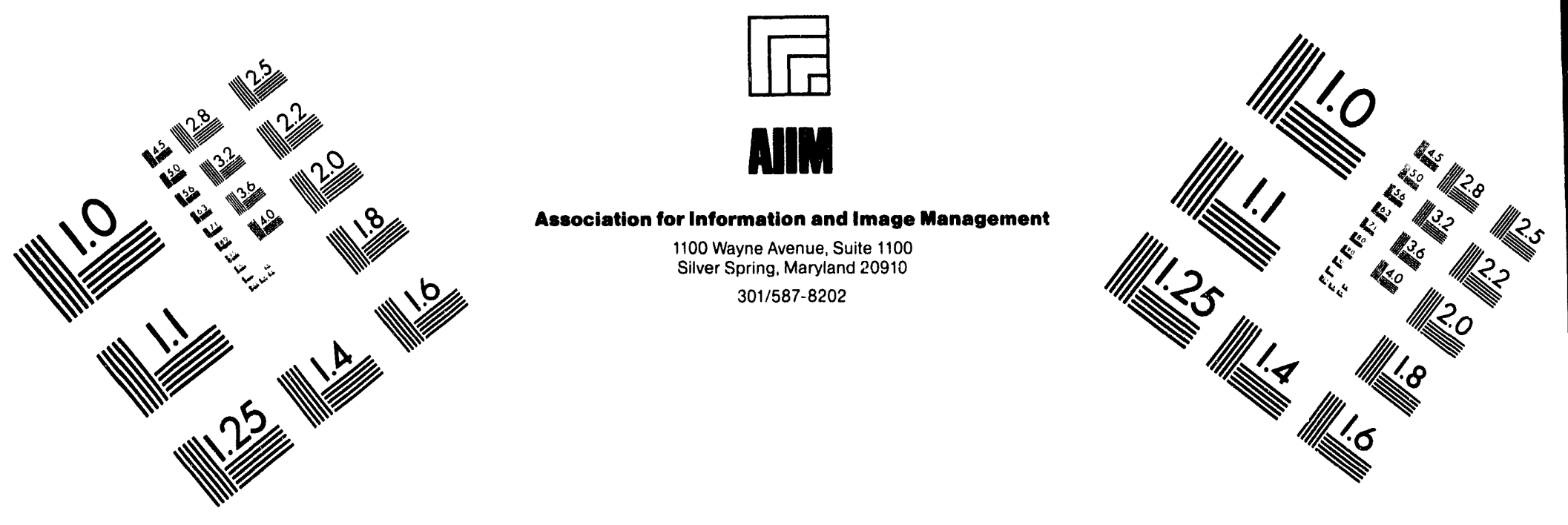

\title{
Centimeter
}

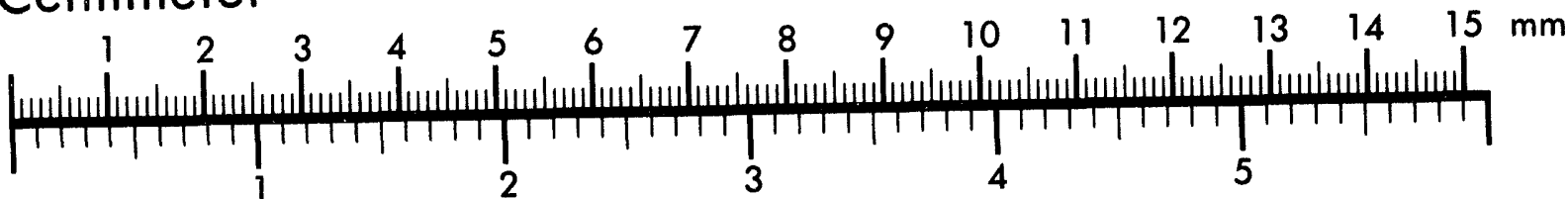
Inches
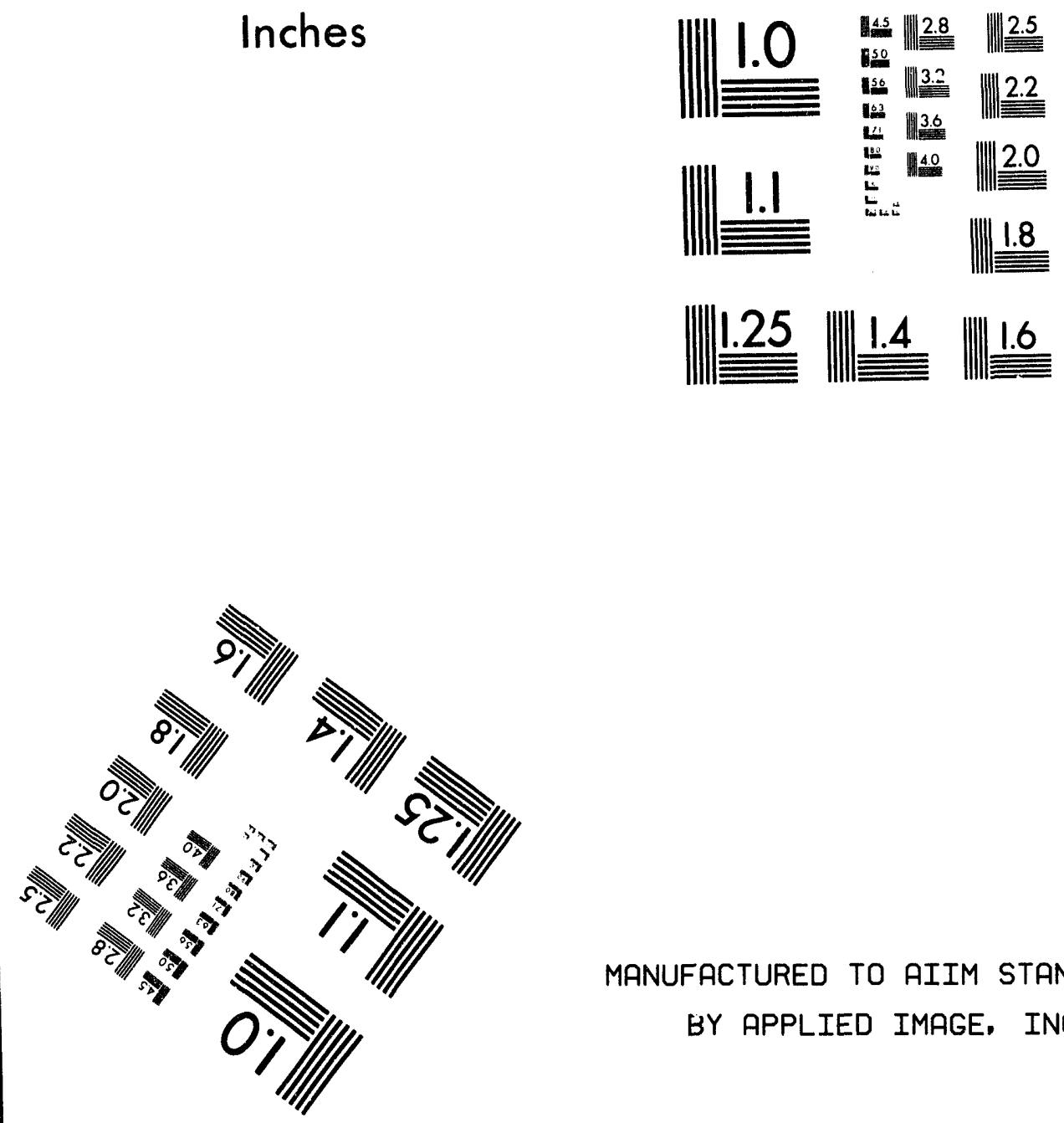

MANUFACTURED TO AIIM STANDARDS

BY APPLIED IMAGE, INC.

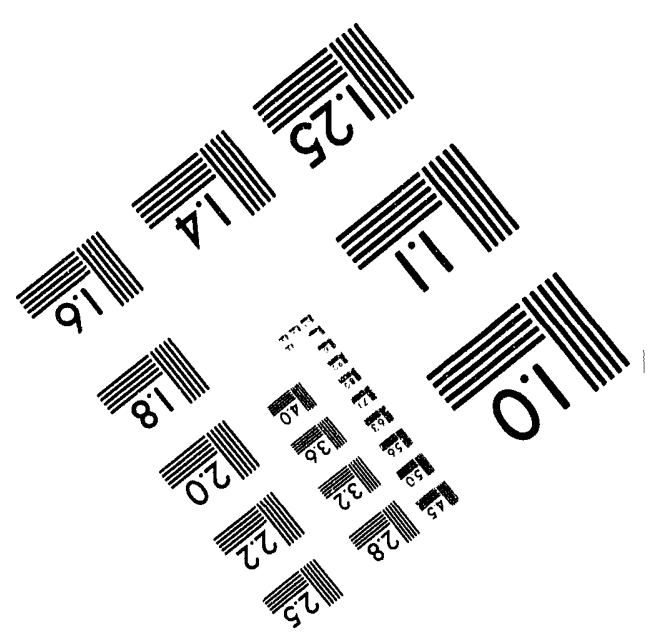



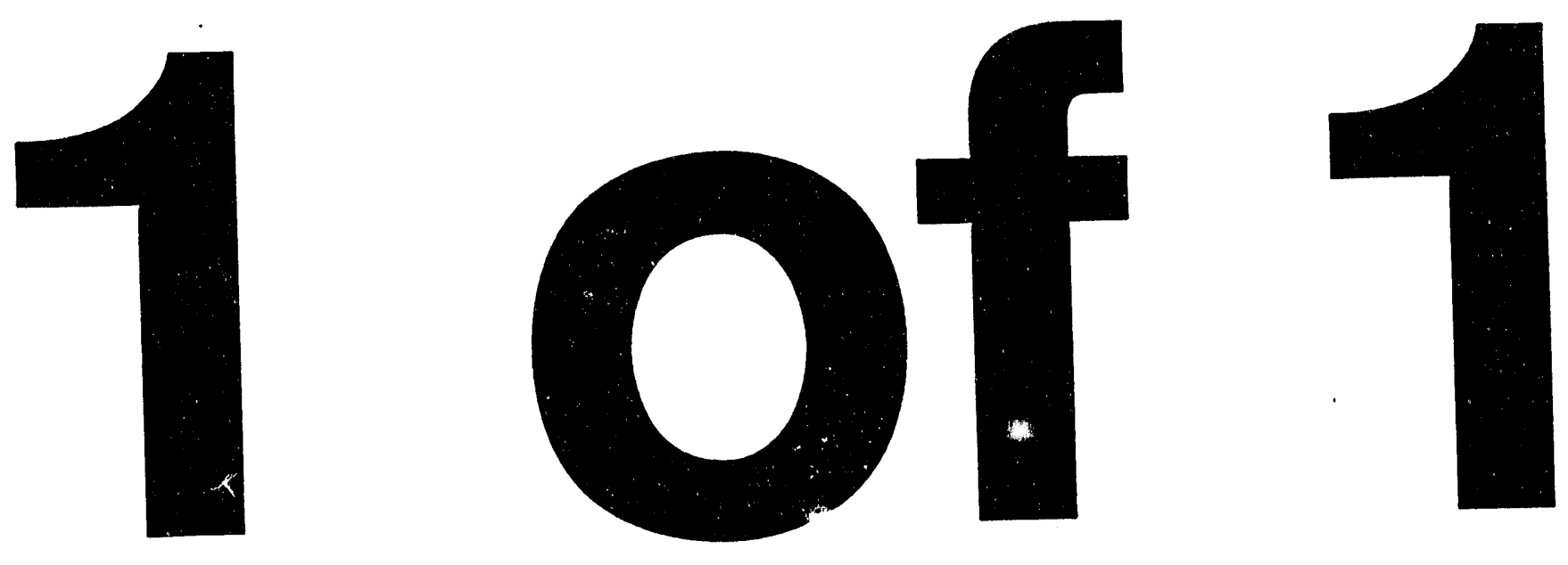


\section{numum enthitit}

HANFORD ATOMIC PRODUCTE OPERATION - RICHLAND, WABHINGTON

DOCUMENT NO.

BW -67208

EENIES AND COPY NO.
DNTE

November 3, 1960

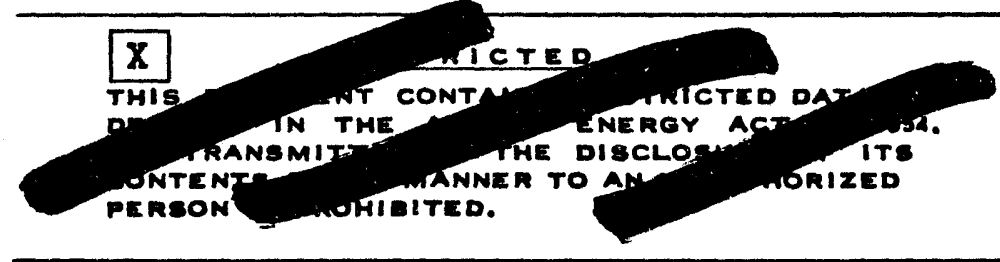

OTHER OFFICIAL CLABBIFIED INFORMATION THIS MATERIAL CONTAINE INFORMATION AFFECTING THE NATIONAL DEFENEE OF THE UNITED BTATEB WITHIN THE MEANING OF THE EBPIONAGE LAWS. TITLE IS, U.\$.C., BECS. TSS AND TBA, THE TRANSMISEION ON REVELATION OF WHICH IN ANY MANNER TO AN UNAUTHORIZED PEREON IS PROMIBITED DY LAW.

THIS DOCUMEM "NOT DE LEFT UNATTEMDE YHERE AN UNAUTHORIV CUARP MEA. WHILE IT IS YO, MESBION AND UNTIL Y

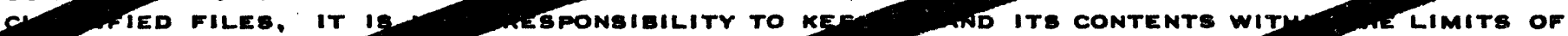
UIS PROJECT ANP FPR UNAUTHORIZED PERBOM OF RESIDENCE IP OBTAIN THEN THE RELATED IS\&UM TO BIGN IN THI BPACE PROVIDED DELOW

TECENICAI BASES FOR C-PITE OVERBORE THST

\section{AUTMOR}

D. H. Curt1ss

M. A. Clinton

W. S. Nechodom

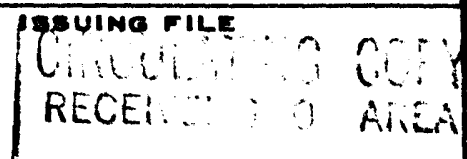

71960

REIUNIV 10

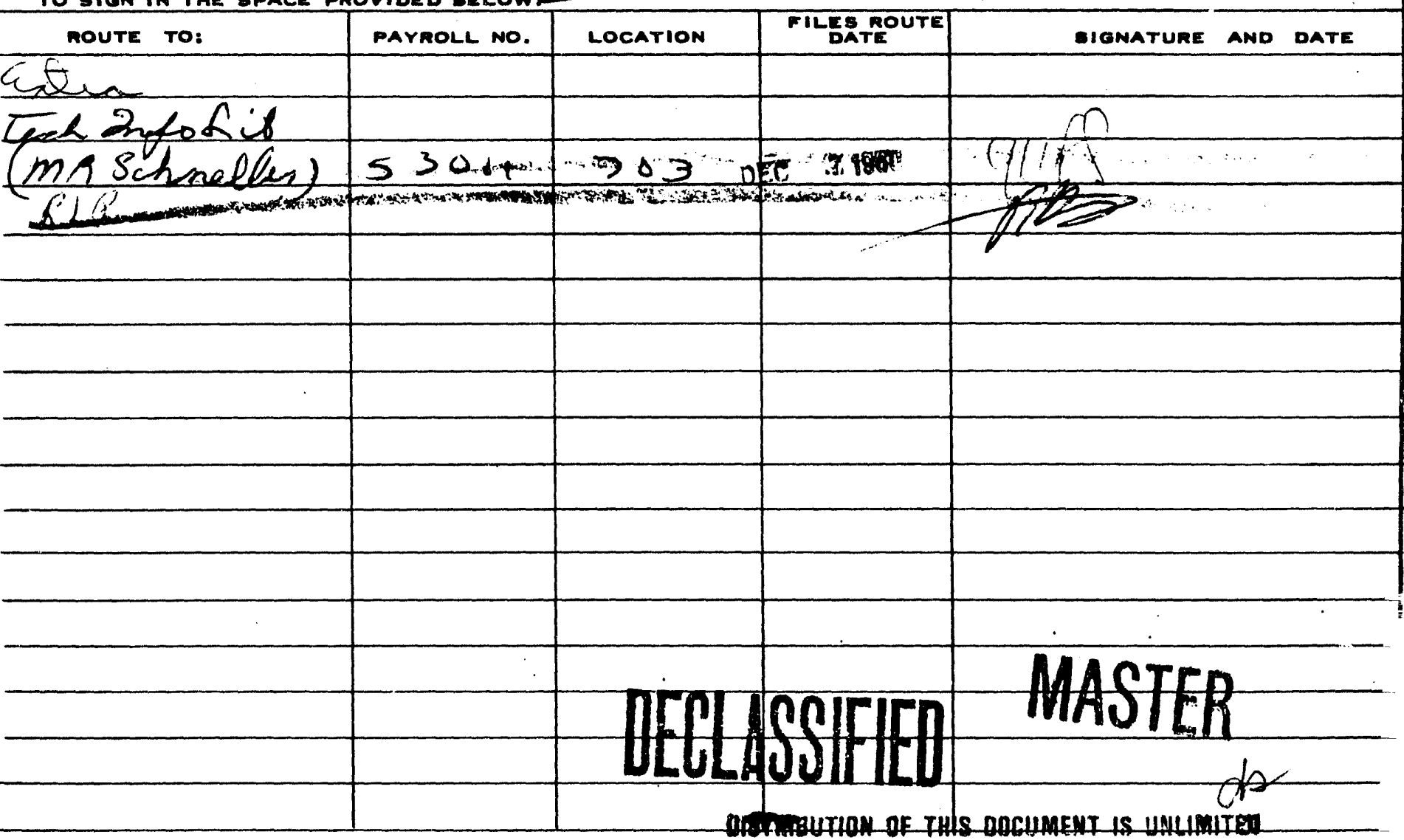

SA-3000-340 (3-57) Alc-ge miemLano, wash

(CLATSSIFICATION) 


\section{DECLSSSFFED}

HW -67208

DISTRIBUTION

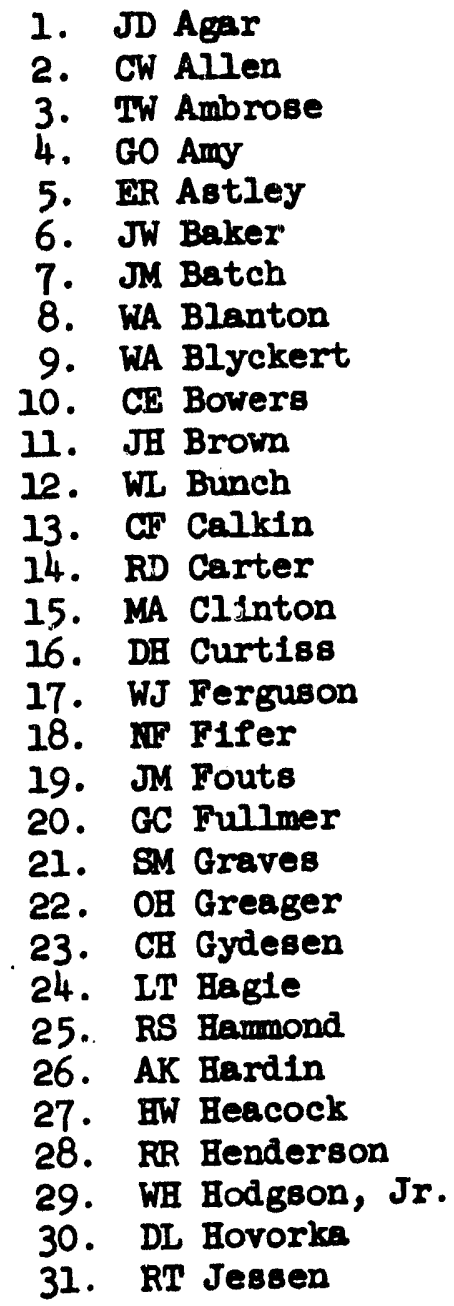

1. JD Agar

2. CW Allen

3. TW Ambrose

4. GO Amy

5. Hatiey

6. JW Baker

7. J Batch

8. WA Blanton

9. WA Blyckert

12. WL Bunch

13. CF Calkin

14. RD Carter

15. MA Clinton

16. DH Curtis8

18. IIf Fifer

19. JM Fouts

20. GC Fullmer

21. SM Graves

22. OH Greager

23. CH Gydesen

24. IT Hagie

25. RS Bammond

26. AK Hardin

27. IW Heacock

28. RR Benderson

29. WH Hodgron

31. RT Jessen
32. IW Lang

33. TH Lyons

34. AR Maguire

35. EB McCerthy

36. CA Munro ... I

37. WS Nechodom

38. DE Newbrough

39. R. H1lson

40. GF Owsley

41. EV Padgett

42. JR Plerce

43. T Prudich

44. RW Reid

45. DL Renberger

46. GJ Rogers

47. ER Rudock

48. OC Schroeder

49. W Seeburger

50. RM Smithers/JC McKay

51. HG Spencer

52. JR Spink

53. RE Trumble

54. FW VanWormer

55. EA Wegener

56. WW Windsheimer

57. EC Wood

58. JR Young

59. Record Center

60. 300. Files

61-75. Extra

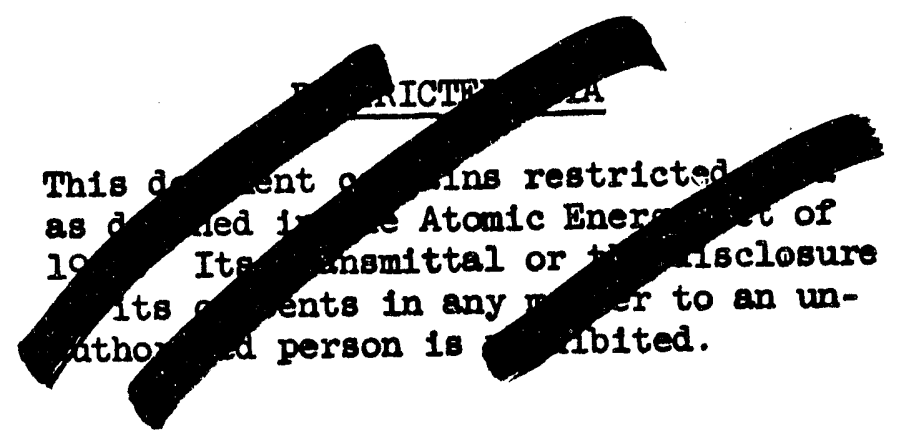

Chedification Cancelod and Changed To

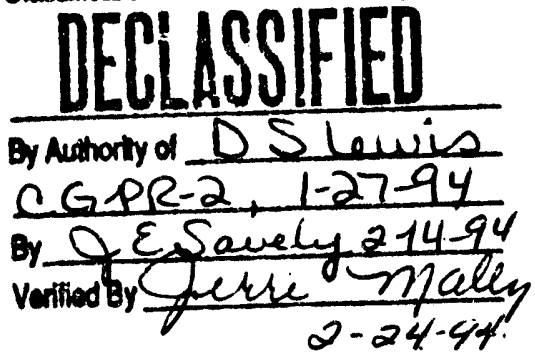

This document consists of 21 pages.
IRRADIATION PROCESSING DEPARTMENT

November 3, 1960 


\section{$-2-$}

HW-67208

INTRODUCTION

The production gains and the economic evaluation of overboring has been extensively treated. Overboring as applied to C-Reactor was most recently discussed in BW-66823, "Major Overboring of C Reactor," by E. C. Wood, et al, dated October 6,1960 (Secret). In this document, the justification for a trial attempt at overboring C-Reactor was given. The overboring test, covered by two production tests (one for overboring and one for fuel 1rradiation), requires the integration of efforts of Equipment Development, Process and Reactor Development, Process Technology, Manufacturing, and the Fuels Preparation Department. In view of this, it appears prudent to collect in one place the current design numbers with a word of explanation regarding their derivation. To this end, this document is dedicated.

\section{SUMMARY}

The various parameters and conditions are summarized in Tables I'through IV. DISCUSSION

Overbore S1ze Determination

Scoping studies for C-pile full-scale overboring included the range from zero to one inch increase in tube outside diameter. The results of this scoping study indicated that for increases in the fuel element diameters beyond about 0.3 inch, the reactor latilce is undermoderated. Consequently, adding moderator to these undermoderated lattices by flooding with water until the "optimum" moderator to uranium ratio is reached results in an increase in reactivity. In the smaller overboring sizes (up to about $0.6 \mathrm{inch}$ ), the reactivity increase so obtained is calculated to be modest, while in the largest overboring sizes (0.8 to 1.0 inch) the calculated maximum pile reactivity attained exceeds the strength of the pile safety control system. The stack flooding incident therefore becomes the limiting consideration in establishing an overbore size. From the results of the scoping study a limit of $.600+.200$ inch was obtained by applying the following criteria:

1. Adding water to the local lattice vold spaces shall elther a) cause a decrease in reactivity, or b) cause an initial increase in reactivity which peaks and subsequently decreases upon further addition of water.

2. The maximum pile reactivity, when all lattices are flooded to the maximum reactivity point shall not exceed the strength of the Ball $3 \mathrm{X}$ safety system plus any in-place supplemental total control devices.

Fuel Element Design Bases (1)

After establishing the approximate amount of overboring, additional criteria were established for the design of the process tubes and fuel elements:

1. $\mathrm{HW}-67032 \mathrm{RD}$, "C Pile Mark I Overbore Fuel Element Design," WS Nechodom, October 6, 1960 (Secret Rough Draft). 


\section{$-3-$ \\ DECLSSSFFED \\ EW-67208}

1. The option of using either ribbed aluminum or smooth bore Zircaloy process tubes in the same graphite channel size and with the same besic fuel element dimensions must be provided.

2. The fuel element shall be of Ire geometry; a three-bumper fuel element shall be used in the ribbed aluminum tubes and a four-footed selfsupported fuel element shall be used in the smooth bore Zircaloy tube.

3. The fuel element shall be sized to provide current central zone tube flows, and designed for equal rates of corrosion on the inner and outer can surfaces.

4. For this 20 tube test the fuel shall be natural uranium.

5. Present fuel element and column lengths shall be maintained.

6. Present central-zone tube power shall be assumed for design purposes.

7. Goal exposure shall be assumed to be $800 \mathrm{MWD} / \mathrm{T}$.

The design procedure used was to choose the dimensions of the ribbed aluminum tube, then design a bumper fuel element for this tube. The fuel element dimensions obtained were fixed, self-support feet were added, and Z1rcaloy tube dimensions were found which would provide the same flow and pressure drop as obtained in the aluminum tube. All calculations were performed with the "FLEX I" 709 program of R. J. Shields.

\section{Basis for Location of 20 Tube Test}

Calculations(1) indicate that the oversized natural uranium fuel element designed for the 20 tube test will generate about $1.5 \pm .08$ times more power per unit length than edjacent normal sized I\&E natural uranium columb. To make test results as representative as possible of future operating conditions 1t appears necessary that each of the 20 overbored channels be located in a region of the reactor where present tube powers are about $\frac{1}{5}$ or 67 percent of central zone tube powers. . Alternatively, within engineeriths ${ }^{51 m i t a t i o n s ~(T A I ~ I I m i t s, ~ e t c .) ~ t h e ~ t e s t ~ c h a n n e l s ~}$ may be located to provide various degrees of operating severity up to a maximum of about 1.5 times the anticipated future power levels at present reactor flows.

\section{Basis for Tube Burnout Protection}

Tube burnout protection procedures are not expected to be different from those currently in use because the variables that effect transient flow instability (front and rear heeder pressure, Panellit pressure, and pressure drop in the rear fittings) are not changed by this test.

A comparison of pressure drop from header to header at 50-51 $\mathrm{gpm}$ under operating conditions in the normal CIIN case and in the overbore geometry shown below: 


\begin{tabular}{|c|c|c|}
\hline & \multicolumn{2}{|c|}{$\Delta p(p B 1)$} \\
\hline & Normal CIII & Overbore \\
\hline Front Header to Front Nozzle & 130 & 45 \\
\hline Active Section of Thube & 205 & 270 \\
\hline Dummy Section of Tube & 5 & 5 \\
\hline Rear Nozzle to Rear Header & 15 & 15 \\
\hline To & 355 & 335 \\
\hline
\end{tabular}

The front and rear fitting pressure drops shown above were derived from exper1mental data. Using these values together with the fact that 355 psi is avaliable for the header to header pressure drop makes about 290 psi available for the active zone in the overbore case. However, the fuel element was purposefully designed for a 270 psi pressure drop to obtain a 20 psi safety margin in the calculations.

Basis for Rib Belght in Ribbed Aluminura Tubes

The rib helght was designed on the basis of obtaining maximum tube iffe. This requires an initial eccentric positioning of the fuel element towards the top of the tube. Tnitially the top of the tube corrodes more rapidly than the bottom. But as the ribs wear and corrode, this trend is reversed. Thus, proper positioning will result in maximum allowable corrosion at both the top and bottom of the tube. Experience in the reactors indicates that rib helght which provides an inftial temperature rise across the top of the tube which 181.2 times the average temperature rise across the annulus is near optimum from a tube life standpoint. This factor is called the " $R$ " value and defined as follows:

$$
R=\frac{\Delta T_{\text {Top of Annulus }}}{\text { AT Average in Annulus }}
$$

Calculations indicate an initial rib helght of 0.090 inch will approximately provide an inftial " $R$ " of I.2. This will raise the top-cí-annulus corrosion rate by 3.5 times, or at $1222 \mathrm{kw}$, to about $5 \mathrm{milg} /$ month as compared to 1.4 on the average as shown in the referenced document. (1) About five to $81 x$ months residence time would be permitted in this case. At higher tube power levels, less time would be allowed. These corrosion rates will be reduced by the coolant mixing caused by the presence of bumpers. However, it is also advisable to use mixer elements if ribbed tubes are used from both the standpolnt of tube and fuel element corrosion. This action will, of course, reduce the "R" value below the desired 1.2. The purpose is to provide the maximum rib helght compatible with both tube and fuel element corrosion. Use of mixers in conjunction with an 0.090 inch $\mathrm{rib}$ helght is considered a reasonable compromise in this case. 
$-5-$

BW-67208

DECLLSSFFED

Fuel Element Performance Consideration

With the exception of a few charges of 1.800 inch oD fuel elements irradiated to low exposure at low temperature in the KER loops, Hanford has bad no experience with fuel elements much above present sizes. Irradiation of these large size Ise elements is necessary to yield the required performance information.

Recent calculations have shown that the stress level within the core of the overbore fuel element should Iie somewhere between that calculated for the present I\&E geometry and that experienced with the solid geometry in which cleavage-type fatlures were observed. The data are summarized below:

\section{Comparative Stress Values}

Fuel Geometry

Solid
Solld
Solld
Overbore Bize
KIII IRE Natural
KIII IRE Enriched

\begin{tabular}{l}
$\begin{array}{c}\text { Operating Level } \\
(\mathrm{kw} / \text { foot })\end{array}$ \\
\hline
\end{tabular}

50

55

60

74

75

88 Relative Stress
poi

102,000

111,000

119,000

70,000

59,000

65,600

Iimited data hsve shown the presence of uranium microcracks in present fuel element geometries. It is not known how such mlcrocracks sre propegated, but one hypothesis suggegts that the relative "rate of change" is more important than absolute power. (2) One might predict the "rate of change" to be greater for the more massive fuel element. While it cannot be predicted that cleavagetype fallures will occur with this overbore geometry, it is believed this fuel is nearer the "splitting" threshold than current fuel sizes. It is not expected that this question can be answered with any degree of assurance as a result of limited Irradiation experience with a 20 tube test. Iimited advance power testIng will be obtained by special location of some of the 20 tubes.

Any increases in power in the future will push the stress levels in these large I\&E's even higher. If the splitting threshold is encountered, fuel geometries with intrinsic lower stress levels will be required. Analytical investigations of rod-in-tube (nongenerating and generating rods) and tube-and-tuke geometries are being started. If any of these should appear at all attractive from a conversion ratio standpoint, fabrication and cost studies will be commenced.

The strength of the AlS1 bond on the present size fuel has always been considered marginal. Bond-rejects, detected on fuel elements in the C-Metal Examination Basin, show some evidence of bond deterioration on present size fuel elements. If bond deterioration 18 a problem, present weaknesses in the AlSi braze may worsen as a result of changes in fuel geometry. Examination of irradiated pieces $w 117$ be made in an effort to define the geometry effect on the irradiated bond.

2. BW-55377, "Analysis and Correlation of HAPO Reactor Experience with Natural Uranium Material," RR Bloomstrand and WI Neef, April 23, 1958 (Secrst) 


\section{$-6-$ \\ DECLLSSFFED \\ HW -67208}

Little work has been done on self-supported design for fuel elements in this welght range. In aluminum tubes, high-bearing loads and galling between the support and tubes my require the development of new materials or support design. HLO has been requested to undertake this problem and should be able to define the magnitude of the aluminum tube wear expected during the chargedischarge operation. In zirconium tubes this problem is not expected to be significant. Current IPR developments will be applicable if necessary.

Geometry is an important variable in the heat treatment of uranium cores. Since a particular heat treatment is used to control the irradiation stability of uranium, it is reasonsble to believe the dimensional stability of oversize fuel elements may be different from present core sizes. Although the magnitude and direction of such changes cannot be estimated at this time, it is belleved the stability should decrease with increased core size. FPD is currently making studies in conjunction with the Feed Material Sites to establish a heat treating cycle which will yleld uranium cores with a desirable orlentation.

Hopefully, the canning process Itself will suggest some of the problems expected from larger-size fuel elements. It has been found in the past that actual manufacturing experience is required to test most geometry changes in fuel design.

Fuel Temperatures

Fuel surface temperatures would not be significantly changed by the use of larger diameter fuel elements in an overbored channel. It was calculated that the increased surface area of the larger elements for the 0.55 inch overbore would decrease the aluminum jacket temperature by only $5^{\circ} \mathrm{F}$. The use of selfsupported fuel elements will provide an increased amount of water mixing within the coolant channel, and this mixing action should result in a more uniform temperature distribution around the fuel surface. Naximum uranium temperatures in the neighborhood of $320^{\circ} \mathrm{C}$ are expected. Currently, maximum uranium tempera-) tures are calculated to be $275^{\circ} \mathrm{C}$.

\section{Fuel Testing Program}

About 1,000 fuel elements are expected to be in production in the 306 pilot plant about December, 1960, with completion schedule for about January 15, 1961. This is expected to yield a sufficient quantity of acceptable fuel elements to load 20 tubes, plus about six additional colums as needed to replace tubes prematurely discharged for measurements. The initial work would be done on existing manual equipment on essentially a hand-made basis. This experience, however, should accurately establish the canning, fabrication and inspection procedures required to support a full reactor conversion.

Using a fixed fuel geometry and enrichment, the irradiation severity can be adjusted for testing purposes by choosing various locations or charge lengths within the reactor. Thus, it 18 proposed that the 20 tubes be divided into 


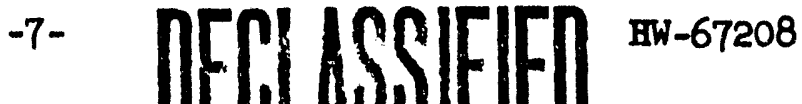

two groups, such that the span of operating conditions expected after a full reactor conversion may be investigated. Post-irradiation measurements should be directed toward dimensional changes, deterforation of uranium or the braze layers, and fuel distortion.

D. H. Curt18s

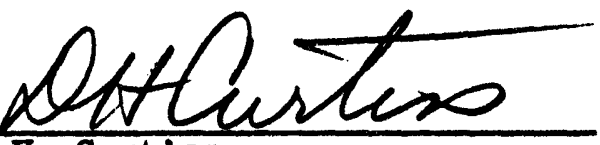

Reactor Engineering Unit

Process \& Reactor Development
In.a.chinton

M. A. CIInton

Reactor Fuels Unit

Process \& Reactor Development

Ors Nechodom

W. S. Nechodom

Reactor Physics Unit

Process \& Reactor Development

$\mathrm{vb}$ 
TABLE I

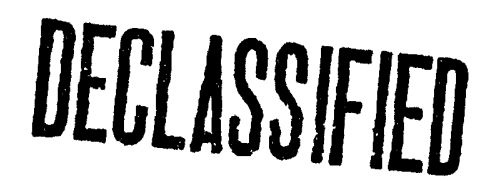

PROCESS TUBE STZE

1. Smooth Bore Zr-2 Process Tube

ID

$2.147^{\prime \prime} \pm .005$

OD

2.250" Max.

พ. T.

$0.040^{\prime \prime} \mathrm{kin}$.

Length

$43^{\prime}+3^{\prime \prime}-0^{\prime \prime}$

2. Bmooth Bore Al Process Tube

ID

$2.147^{\prime \prime} \pm .005^{\prime \prime}$

OD

2.317" Max.

พ. T.

$0.075^{\prime \prime}$ Min.

Iength

$43^{\prime}+3^{\prime \prime}-0^{\prime \prime}$

Material

1100 (2s) or 6063 (638)

3. RIbbed Al Process Tube

ID

$2.155^{\prime \prime} \pm .003^{\prime \prime}$

$O D$

2.317" Max.

W. T.

$0.075^{\prime \prime}$ Min.

Length

$43^{\prime}+3^{\prime \prime}-0^{\prime \prime}$

RIb Height

$0.090 " \pm .002 "$ 
TABILE II

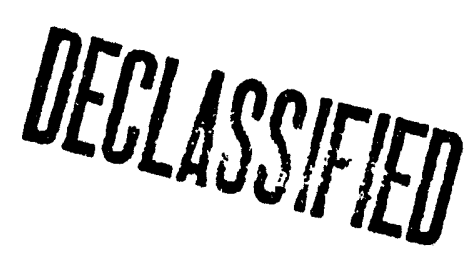

\section{FUEL SIRE}

\section{Finiahed Product Core}

OD

ID

Effective Length $1.991^{\prime \prime}$

$0.339^{\prime \prime}$

8.865" $1.883^{\prime \prime}$

$0.452^{\prime \prime}$

8.325"

Maximm clrcumscribed diameter of 8.8.F.E. $2.135^{\prime \prime}$

Ra1l helght on S.S.F.E.

$0.065^{\prime \prime}-0.070^{\prime \prime}$

Length of support of bumper

$\sim 1-1 / 8^{\prime \prime}$

Over-all length of support or bumper

2-1.16"

D1stance of support or bumper from end of fuel element

1-1/4"

Bumper Helght on bumper fuel element 
TUBE LOCATION

Criteria for choice of location was to place 16 channels so as to typlfy existing current central zone tube powers at C-Reactor and place four channels so as to pilot higher specific slug power. Further, the location of all channels will be such that they are not adjacent to VSR channels.

1. 12 channels along row 3 , or equivalent.

2. 8 channels divided into 2 rows of 4 each; each row to be midway between rod banks and 2 of each of 4 locsted in 3rd lattice unit with remaining 2 of that 4 located in maximm powered region on near side with 3 lattice units separation. Top row of 4 channels located not higher than row 33 .

3. The 4 channels located in maximum power region to be short charged with 20 elements and will have $60 \%$ higher specific slug power than adjacent tubes, maximum flow of $55 \mathrm{gpm}$ and maximum outlet temperature of $120^{\circ} \mathrm{C}$.

4. Tubes in 3rd lattice unit would have a maximum power as follows: (Assume $95^{\circ} \mathrm{C}$ bulk and 94,000 spm.)

\begin{tabular}{rrrrrr} 
& \multicolumn{2}{c}{$3 \mathrm{rd}$ Lattice Overbore } & & \multicolumn{2}{c}{ Central Zone } \\
\cline { 2 - 3 } $0^{\circ} \mathrm{C}$ Inlet & $1566 \mathrm{kw}$ & $117^{\circ} \mathrm{C}$ outlet & & 1385 & 104 \\
$12^{\circ} \mathrm{C}$ Inlet & $1368 \mathrm{kw}$ & $115^{\circ} \mathrm{C}$ outlet & 1210 & 103 \\
$20^{\circ} \mathrm{C}$ Inlet & $1235 \mathrm{kw}$ & $112^{\circ} \mathrm{C}$ Outlet & 1092 & 102
\end{tabular}


TABLE IV

\section{DECLLSSFIED}

\section{FLOW ASSUMPIONS}

1. Hominal tube flow in 12 channels in row 3 is $50.6 \mathrm{cpm}$.

2. Flow in short charged columns not in excess of $55 \mathrm{spm}$ with waximum permissible tube outlet water temperature of $120^{\circ} \mathrm{C}$.

3. Naximum front Pltting pressure drop at $50.6 \mathrm{gpm}$ is $45 \mathrm{ps} 1$.

4. Calculated maximum pressure drop for active zone at $50.6 \mathrm{cpm}$ is 270 psi.

5. Safety factor for calculational errors is $20 \mathrm{psi}$. 

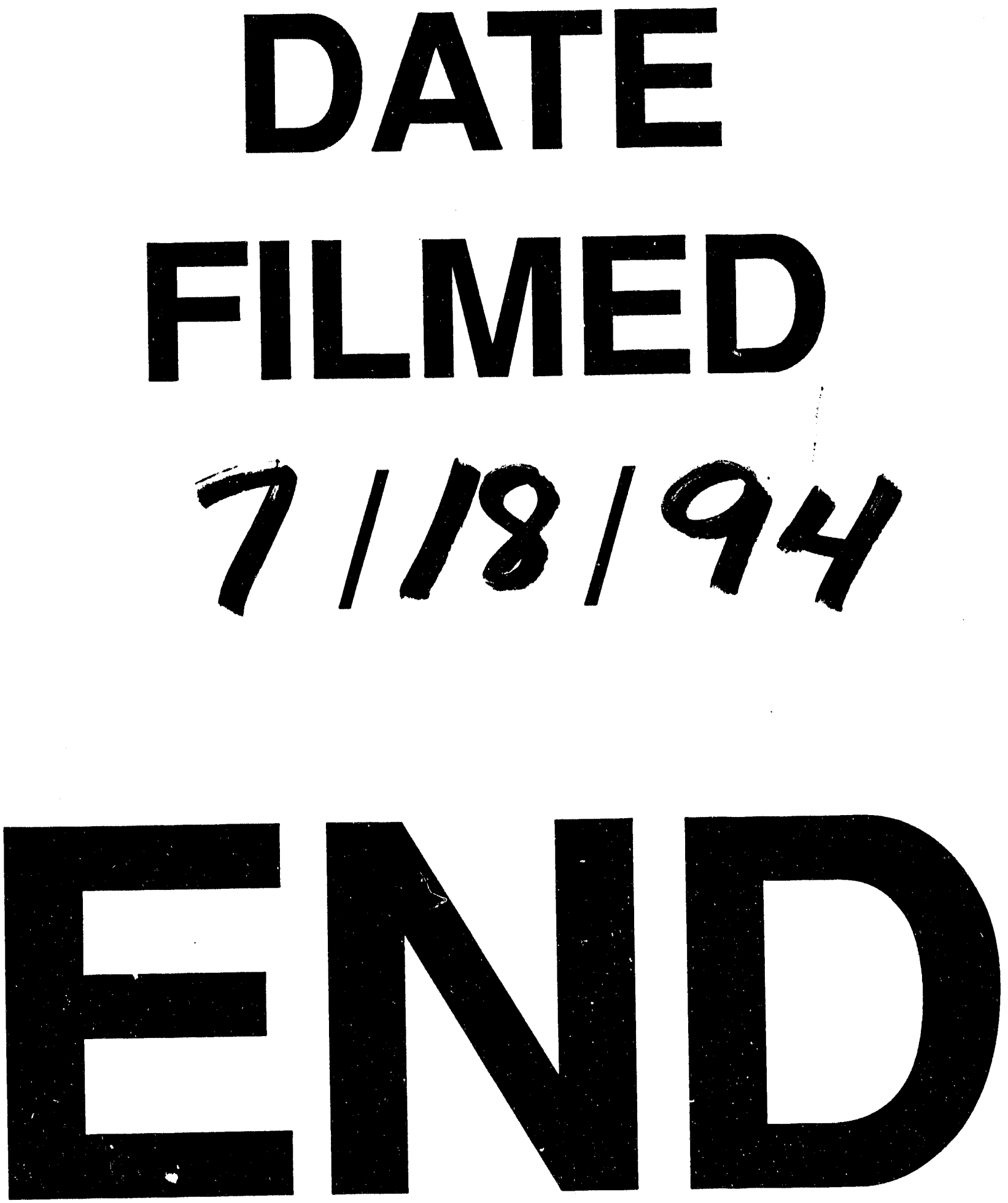

IV 
1 